Research Articles

\title{
X-ray microanalysis of northeastern Quintana Roo aquatic biota, Mexico: evidence of hazard metals presence
}

\author{
Jesús Alvarado-Flores ${ }^{1}$, Silvia Beatriz Andrade-Canto ${ }^{2}$ \\ José Adán Caballero-Vázquez ${ }^{1}$ \& Antonio Almazán-Becerril ${ }^{1}$ \\ ${ }^{1}$ Centro de Investigación Científica de Yucatán, A.C., Unidad de Ciencias del Agua \\ Cancún, Quintana Roo, México \\ ${ }^{2}$ Centro de Investigación Científica de Yucatán, A.C., Unidad de Biotecnología \\ Mérida, Chuburná de Hidalgo, México \\ Corresponding author: Jesús Alvarado-Flores (jesus.alvarado@cicy.mx)
}

\begin{abstract}
Microanalysis of elemental composition using dispersive energy X-ray is a biomonitoring tool to identify hazard metals. Using scanning electron microscopy/energy dispersive X-ray spectrometry, we studied the bioaccumulation of toxic metals in the lorica of diatoms, dinoflagellates, rotifers, cladocerans, copepods and fish scales in the aquatic ecosystems of northeastern Quintana Roo, Mexico. The study was carried out in the coastal zone, where samples were collected in 16 exposed bodies of water, including dolines, mangroves and lagoons. Microanalysis of the most abundant organisms revealed evidence of the presence of essential trace elements and metals ( $\mathrm{Ag}, \mathrm{Al}, \mathrm{Br}, \mathrm{Cd}, \mathrm{Cu}, \mathrm{Fe}, \mathrm{Hg}, \mathrm{Pb}$ and $\mathrm{Zn}$ ) in the lorica and scales. Furthermore, interpolation maps of the northeastern zone of Quintana Roo were produced to pinpoint critical pollution zones of $\mathrm{Cd}, \mathrm{Hg}$ and $\mathrm{Pb}$, elements that are deemed toxic to the health of humans and aquatic ecosystems. In conclusion, elemental microanalysis of species native to the Mexican state of Quintana Roo using X-ray is a powerful tool for aquatic and toxicological biomonitoring of hazardous metals.
\end{abstract}

Keywords: heavy metals; bioindicators; plankton; Yucatan Peninsula

\section{INTRODUCTION}

A karstic aquifer found in the northern and southern zones of the Yucatan Peninsula (YP) is the largest source of freshwater supply for use and consumption in agriculture and tourism (CNA, 2016). This coastal hydrogeological system is economically and ecologically relevant because terrestrial and surface aquatic ecosystems interact transversally and horizontally and are the location where most of the anthropogenic activities take place. Such characteristics make this karstic aquifer a dynamic and vulnerable spatial unit whose extension varies because its limits are defined not only by environmental and geological characteristics but also by political and administrative concepts (Hernández-Arana et al., 2015). The increase in anthropogenic activities in northeastern Quintana Roo has had adverse effects on aquatic ecosystems, pri- marily an increase in organic and inorganic pollution (Oliva \& Fernández-Espinosa, 2007; Avila et al., 2011; Metcalfe et al., 2011). Related to this, there is a large variety of freshwater, saltwater, or brackish ecosystems in the YP (Schmitter-Soto et al., 2002; TorrescanoValle \& Islebe, 2015). In these environments, aquatic species are the link between the abiotic conditions and other biotic components of the trophic network created in groundwater-dependent ecosystems. Overall, aquatic species bridge the gap between primary producers and secondary consumers. In that direction, a high biodiversity of aquatic biota has been found in the YP (Herrera-Silveira \& Comín, 2000; Alvarez-Cadena et al., 2007; Suárez-Morales et al., 2013). Moreover, previous reports revealed the magnitude of pollution by metals in aquatic ecosystems in the coastal zone of Quintana Roo. According to our database of the Project Conacyt $N^{\circ} 2944$ (Perez-Yañez, pers. comm.), we found

Corresponding editor: Sergio Contreras 
that there are 412 reports of 19 heavy metals reported in Quintana Roo between 1987 and 2018. Of these reports, there were 39 for $\mathrm{Cd}(12 \%$ of the data) and 53 for $\mathrm{Pb}$ (14\% of the data).

An example of this pollution has been reported in the sea of the Mexican Caribbean, where the presence of $\mathrm{Cd}, \mathrm{Cr}, \mathrm{Cu}, \mathrm{Fe}, \mathrm{Ni}, \mathrm{Mn}, \mathrm{Pb}$ and $\mathrm{Zn}$ has been reported in sediments, water and marine organisms such as fish, echinoderms, corals and bivalves (Fernández et al., 2007). Likewise, $\mathrm{Cr}, \mathrm{Cu}, \mathrm{Fe}, \mathrm{Mn}$ and $\mathrm{Pb}$ have been detected in the leaves and rhizomes of marine seagrass Thalassia testudinum in the coral reef zone of Puerto Morelos, Quintana Roo (Whelan III et al., 2011). The most studied metal in underground water in the northeastern zone of the Yucatan Peninsula is Cd. Indeed, there are reports of $\mathrm{Cd}$ concentrations that exceed the maximum limits permitted by Mexican regulations (Avila et al., 2012). $\mathrm{Cd}^{+2}$ is hazardous to aquatic organisms and human health. $\mathrm{Cd}^{+2}$ is listed seventh by the Agency for Toxic Substances and Disease Registry (ATSDR, 2016), and has been listed by the US Environmental Protection Agency as a priority contaminant. $\mathrm{Cd}^{+2}$ is one of the most toxic elements to which humans can be exposed at work or in the environment (Bernard, 2008), causing severe adverse effects by chronic exposure. However, there are few studies of other metals and even fewer studies of metal bioaccumulation in zooplankton, phytoplankton and fish in northeastern Quintana Roo. Due to the lack of eco-toxicological studies and environmental monitoring of hazard metals, the damage to the ecosystem and effects on human health due to metals are unknown in Quintana Roo.

Metals can bioaccumulate and biomagnify in biota at the primary and secondary trophic levels when they are persistent and bioavailable (Sternbeck et al., 2002; Rubio-Franchini et al., 2008). In this regard, heavy metal is toxic to aquatic species at a level of lethality when its concentration exceeds the limit allowed in a water system by environmental legislation (Rainbow \& Luoma, 2011). However, if this limit is not exceeded, the aquatic species may continue a normal life cycle. Unfortunately, heavy metals are not biodegradable and accumulate in biota (Walker et al., 2006), so the aquatic biota eventually bioaccumulates the metal and reach a degree of poisoning that is lethal.

Another example related to metal toxicity and toxicodynamics in aquatic biota is $\mathrm{Pb}$. The ion $\mathrm{Pb}^{+2}$ is generally present in two oxidation states, $\mathrm{Pb}^{+2}$ and $\mathrm{Pb}^{+4}$, and $\mathrm{Pb}^{+2}$ predominates in aquatic habitats (Landis et al., 2004). The environmental occurrence of $\mathrm{Pb}$ is from natural sources and anthropogenic activities, and $\mathrm{Pb}^{+2}$ has more industrial and other applications (Mudgal et al., 2010; Tchounwou et al., 2012). For example,
Rubio-Franchini et al. (2008) suggest that biomagnification of $\mathrm{Pb}$ through at least one trophic level can occur in freshwater systems. Biomagnification of $\mathrm{Pb}$ detected in the rotifer Asplanchna brightwellii might be explained in part by the effects of this voracious predator on young of the herbivorous cladoceran Moina micrura.

In light of the significant dangers that result from metal bioaccumulation, the present study was undertaken. Using scanning electron microscopy/energy dispersive X-ray spectroscopy, as an eco-toxicological biomonitoring tool for hazard metals, we studied metal accumulation in lorica and scales of aquatic biota. Lorica is mainly composed of chitin, a polysaccharide associated with inorganic substances, and is a constituent of invertebrates such as crustaceans, annelids, mollusks and insects. Scales are mainly composed of calcium phosphate and calcium carbonate and are present in fish (Péqueux \& Lignon, 1991; Juárez-de la Rosa et al., 2015; Gómez et al., 2016). Both tissues are excellent indicators of bioaccumulation and biomagnification of metals. The presence of metals in the lorica or scales of aquatic species indicates that they were exposed to metals during their life cycle. Because they were bioavailable, the metals were then absorbed by aquatic biota. Finally, metals are biomagnified in ecosystems or deposited in the sediments.

\section{MATERIALS AND METHODS}

\section{Zooplankton, phytoplankton and fish collection}

We analyzed data collected over the period from 2014 to 2016; several random collection campaigns were undertaken with no seasonal pattern defined for zooplankton, phytoplankton and fish in dolines, coastal lagoons and mangrove zones in the state of Quintana Roo. In total, we analyzed 16 sites. A net with a mesh clearance of $45 \mu \mathrm{m}$ was used to collect zooplankton and phytoplankton, following the methodology of RicoMartínez \& Silva Briano (1993). The collections correspond to the project Cathedra's CONACYT $\mathrm{N}^{\circ} 2944$ monitoring of aquatic biodiversity. The 100 $\mathrm{mL}$ samples were divided into two halves; $50 \mathrm{~mL}$ of the sample was left unpreserved to keep organisms alive, and $50 \mathrm{~mL}$ were preserved in formalin at $5 \%$. The identification and separation of the organisms were carried out using a Stemi and Axiovert stereo microscope, Zeiss brand. The identification was made using pictorial and dichotomic keys (Koste, 1978; Stemberger, 1979; Nogrady \& Pourriot, 1995; Nogrady \& Segers, 2002; Elías-Gutiérrez, 2008). Fish were collected with a $3 \mathrm{~mm}$ cast net using the fishing method by time unit in each site. Fish were preserved in $96 \%$ alcohol and identified at family and genus level. Site databases, as well as species reported per site, are broken down in the supplementary material. 


\section{Rotifer cultivation and exposition to $\mathbf{C d}$ and $\mathbf{P b}$}

We cultivate two species of rotifers of sample collected, to using as groups control in metal detection, scanning electron microscopy/energy dispersive X-ray. Both strains were established as monoclonal cultures: Brachionus cf ibericus Cancun strain (marine organism) and Lecane bulla (freshwater organism) collected in northeastern Quintana Roo, and culture in the laboratory following the protocols by PérezLegaspi \& Rico-Martínez (1998). Polystyrene plates with 24 wells (Costar brand) were used to culture and maintain the cultures. Rotifers were fed on the microalga Nannochloropsis oculata (LB2194 strain from the University of Texas Collection) grown in Bold's Basal medium (Nichols, 1973). Rotifers were incubated in a bioclimatic cabinet (Thermo Scientific brand) at a temperature of $25 \pm 2^{\circ} \mathrm{C}$, with a photoperiod of $12 \mathrm{~h}$ light:dark cycle. Later, when each well-reached densities of $>100$ individuals, the organisms were transferred to $10 \mathrm{~mm}$ Petri dishes and kept for a three month adaption period before the $\mathrm{Cd}$ and $\mathrm{Pb}$ exposure experiments. Water to prepare the culture medium for L. bulla was reconstituted water or freshwater medium according to the US Environmental Protection Agency (1985). Water for the Brachionus cf ibericus Cancun strain was saltwater prepared at $15.0 \mathrm{~g} \mathrm{~L}^{-1}$ with RedSea ${ }^{\circledR}$ brand salt.

The metal exposure experiments were performed as follows. One hundred rotifers of different ages were placed in $1 \mathrm{~mL}$ of culture medium in a 24-well plate according to the species under study. They were exposed to $\mathrm{Cd}$ and $\mathrm{Pb}$ (atomic absorption standards Fluka ${ }^{\circledR}$ brand at a nominal concentration of $1 \mathrm{mg} \mathrm{mL}^{-1}$ concentration in $2 \% \mathrm{HNO}_{3}$ ) for $24 \mathrm{~h}$ under culture conditions, with three replicas for controls without metals. At the end of the experiment, the organisms were washed six times with deionized water (three rounds in a vortex for 3 min per wash) and then microcentrifuged to concentrate the specimens at the bottom. Next, the samples were preserved in 5\% formalin and placed in an Eppendorf tube in a final volume of $1 \mathrm{~mL}$. Finally, the Eppendorf vials of each experiment for the species and each toxicant were processed for analysis with scanning electron microscopy/energy dispersive X-ray spectrometry (SEM/EDS), based on the protocol by Alvarado-Flores \& Rico-Martínez (2017).

Micro and macroelement analysis by scanning electron microscopy/energy dispersive X-ray spectrometry (SEM/EDS)

The analysis of organisms from environmental samples and laboratory-cultured rotifer strains was carried out based on the protocols of Alvarado-Flores \& RicoMartínez (2017). The organisms from the environmental samples included: Phytoplankton (3 diatoms, 4 dinoflagellates), Zooplankton (13 cladocerans, 22 copepods, 39 rotifers) and three fishes. There were 27 Brachionus cf ibericus Cancun strain and 24 Lecane bulla Cancun strain laboratory cultures. Initially, all samples were dehydrated with gradual concentrations of alcohol $(60,70,80$ and 96\%) for $30 \mathrm{~min}$ in each alcohol in a refrigerator at $4^{\circ} \mathrm{C}$. Excess moisture was eliminated with liquid $\mathrm{CO}_{2}$ using a critical point dryer. Determination of the elements included the entire cuticle and scales of the fish, being careful to preserve the integrity of the mounted organisms and using the best conditions for the analysis. Then, the samples were covered in a gold layer using a DESK II camera to run the analysis and take the photographs. Microanalysis of the elemental composition was represented by histograms and images of the distribution of the chemical elements in the samples; the spectrum was obtained using a software program (INCA suite 3.04, Oxford 2.6 statistical instrument) that captures the photons emitted by the samples for a specific time and classifies them according to their energy. Microanalysis conditions were as follows: accelerating voltage = $20.00 \mathrm{kV}$; live time $=50 \mathrm{~s}$; elevation $=35$; number of iterations $=4-6$. The spectrum appears as a histogram in which the $x$-axis represents energy units (kilo electron volts), and the $y$-axis represents intensity. The $\mathrm{X}$-ray penetration range of $1,000 \mathrm{~nm}$. The average penetration range in X-ray analyses is $2.275 \mu \mathrm{m}$ (Segura-Noguera et al., 2012). INCA suite 3.04 was used for the quantitative analyses (the total composition percent of the detected elements). This technique is both qualitative and quantitative (Sigee et al., 1998; Newbury \& Ritchie, 2013: Alvarado-Flores \& RicoMartínez, 2017).

\section{Spatial representation and data analysis}

A database was compiled with the elemental composition data and the geographic location of the species. This database was applied for descriptive statistics. The Kruskal-Wallis and one-way variance analysis (ANOVA) tests were run using the software program Statistica 7.0 (Statsoft Inc., 2004) to determine the elemental composition by taxonomic group (supplementary material). Interpolation maps for $\mathrm{Cd}$, $\mathrm{Hg}$ and $\mathrm{Pb}$ detected in the aquatic biota were produced using QGIS 2.14.0 Essen software. Raster interpolation and clipper extraction were carried out; color interpolation was linear using single-band pseudocolor rendering, whereas the weighting of the interpolation was inverse to the distance (IDW) using the NeighborJoining Algorithm. 


\section{RESULTS}

The SEM/EDS X-ray images of six groups of aquatic biota revealed a complex, layered microstructure and artifacts (Fig. 1). However, the deposition of elements always depended on biochemical and physiological processes. In this study, we used the lorica and scales as indicators of metal accumulation. The quality of images was related to working conditions (supporting grid, the microscope chamber and the protection layer) and origins (all samples were from the environment). The composition of elements in lorica and scales of the six groups are shown (Tables 1-2).

The lorica and scales of Quintana Roo aquatic biota contain macroelements $\mathrm{Ca}, \mathrm{K}, \mathrm{Na}, \mathrm{Mg}, \mathrm{P}, \mathrm{S}$ and $\mathrm{Si}$, microelements $\mathrm{Al}, \mathrm{Cl}, \mathrm{Cu}, \mathrm{Mn}$ and $\mathrm{Zn}$, and hazardous metals (considered toxic for human and aquatic biota health) $\mathrm{Cd}, \mathrm{Hg}$ and $\mathrm{Pb}$. The elemental composition percentages between the taxonomic groups (diatoms, dinoflagellates, rotifers, cladocerans, copepods and fish) are statically significantly different $(P<0.05)$. The basic statistical descriptions are shown in Tables 1 and 2, and the detailed statistics are available in the supplementary data for all the species. Out of 95 specimens, global metal detection in biota is as follows: $\mathrm{Al}$ in $42, \mathrm{Br}$ in $4, \mathrm{Cd}$ in $2, \mathrm{Cu}$ in $18, \mathrm{Fe}$ in $1, \mathrm{Hg}$ in $2, \mathrm{~Pb}$ in 19 and $\mathrm{Zn}$ in 2.

The high abundance of $\mathrm{C}$ and $\mathrm{O}$ as major constituents is evident. The next highest abundance metals were $\mathrm{Ca}$ and $\mathrm{Si}$. As shown in Table 1, the highest weight $\%$ of $\mathrm{Hg}$ is in cladocerans, the highest weight $\%$ of $\mathrm{Pb}$ is in rotifers, and $\mathrm{Cd}$ has the same weight $\%$ in cladocerans and copepods. As shown in Table 2, Pb has a lower \% weight in dinoflagellates than in fish. In general, macroelements $\mathrm{Ca}, \mathrm{Na}, \mathrm{Mg}, \mathrm{S}, \mathrm{Si}$ and $\mathrm{P}$ are statistically significantly different $(P<0.0001)$ between the six groups of aquatic biota, whereas $\mathrm{K}(P$ $=0.4845)$ is not. Microelements $\mathrm{Al}(P=0.0084)$ and $\mathrm{Cl}$ $(P=0.0189)$ are statically significantly different, and $\mathrm{Cu}(P=0.4499)$ is not. $\mathrm{Pb}$ was the only metal in which statistically significant differences were noted between the six groups $(P=0.0008)$.

$\mathrm{Cd}$ was detected in cladocerans (Ceriodaphnia cornuta) and copepods (Harpaticoidea spp.), whereas $\mathrm{Hg}$ was detected only in the Cladocera C. cornuta. $\mathrm{Pb}$ was mainly found in the rotifers Brachionus, Lecane and Keratella, as well as in two diatoms (Navicula sp., Cocconeis sp.) and two dinoflagellates (Pinnularia sp., Ceratium sp.) Overall, $\mathrm{Pb}$ was the most abundant metal recorded for the biota, followed by $\mathrm{Cd}$ and $\mathrm{Hg}$.

The animal group accumulated $\mathrm{Cd}, \mathrm{Hg}$ and $\mathrm{Pb}$ in the zooplankton group consisting of rotifers, cladocerans and copepods, whereas the phytoplankton group consisting of diatoms and dinoflagellates, as well as the fish group, only accumulated $\mathrm{Pb}$. Differences in the detection of groups of aquatic species helped us to understand the distribution of $\mathrm{Cd}, \mathrm{Hg}$ and $\mathrm{Pb}$, in the state of Quintana Roo, mainly, using an analysis of spatial patterns distribution of detected metal concentrations (shown in the interpolation maps of metals in Fig. 2).

The interpolation of metals $\mathrm{Cd}, \mathrm{Hg}$ and $\mathrm{Pb}$ detected in aquatic biota reveals patterns of metal distribution that are also observed for northeastern Quintana Roo. $\mathrm{Cd}$ and $\mathrm{Hg}$ are located between Puerto Morelos and Benito Juárez in northeastern Quintana Roo, whereas $\mathrm{Pb}$ is located along the entire coastline of Quintana Roo.

As a control experiment, we also studied the presence of $\mathrm{Cd}$ and $\mathrm{Pb}$ using microanalysis of two laboratory rotifer species intoxicated for $24 \mathrm{~h}$ at $1 \mathrm{mg}$ $\mathrm{L}^{-1}$. We found that $\mathrm{Cd}$ was not detected in either of the two species compared with the non-intoxicated control organism. $\mathrm{Pb}$ was detected in 15 out of 15 Brachionus cf. ibericus Cancun strain, and significant differences compared with non-intoxicated organisms were observed $(P=0.03)$. For Lecane bulla, $\mathrm{Pb}$ was detected in only one of 16 specimens (see Tables 3 and 4 for details of the elemental percentage composition of the intoxicated and non-intoxicated groups). The presence of $\mathrm{Pt}, \mathrm{Rb}$ and $\mathrm{Au}$ in animals is a product of contamination during the gold-coating process for which these metals are used.

\section{DISCUSSION}

The elemental microanalysis of the lorica of rotifers, cladocerans, copepods, dinoflagellates, diatoms and fish scales in northeastern Quintana Roo is an ideal qualitative tool for toxicological biomonitoring of pollution by metals. This method allowed us to identify the presence of hazardous metals $\mathrm{Cd}, \mathrm{Hg}$ and $\mathrm{Pb}$, as well as micro- and macro elements $(\mathrm{Al}, \mathrm{Ca}, \mathrm{Cl}, \mathrm{Cu}, \mathrm{K}$, $\mathrm{N}, \mathrm{Mg}, \mathrm{Mn}, \mathrm{P}, \mathrm{S}, \mathrm{Si}$ and Zn).

The biota absorbs elements for structural and physiological functions, and lorica, due to its characteristics, contains most of the elements present in water (Péqueux \& Lignon, 1991; Juárez-de la Rosa et al., 2015). In general, Rotifera has $82 \%$, Cladocera, $68.2 \%$, Dinoflagellata, $54.5 \%$, such as fishes and diatoms $36.4 \%$. All the elements recorded in the 95 specimens studied have already been reported in hydrogeology studies carried out on underground water in the YP (Schmitter-Soto et al., 2002; Gondwe et al., 2010; Sánchez-Sánchez et al., 2015). Therefore, our results confirm our research hypothesis that lorica and scales of the aquatic biota of Quintana Roo are indicators of organic pollutant bioaccumulation. 

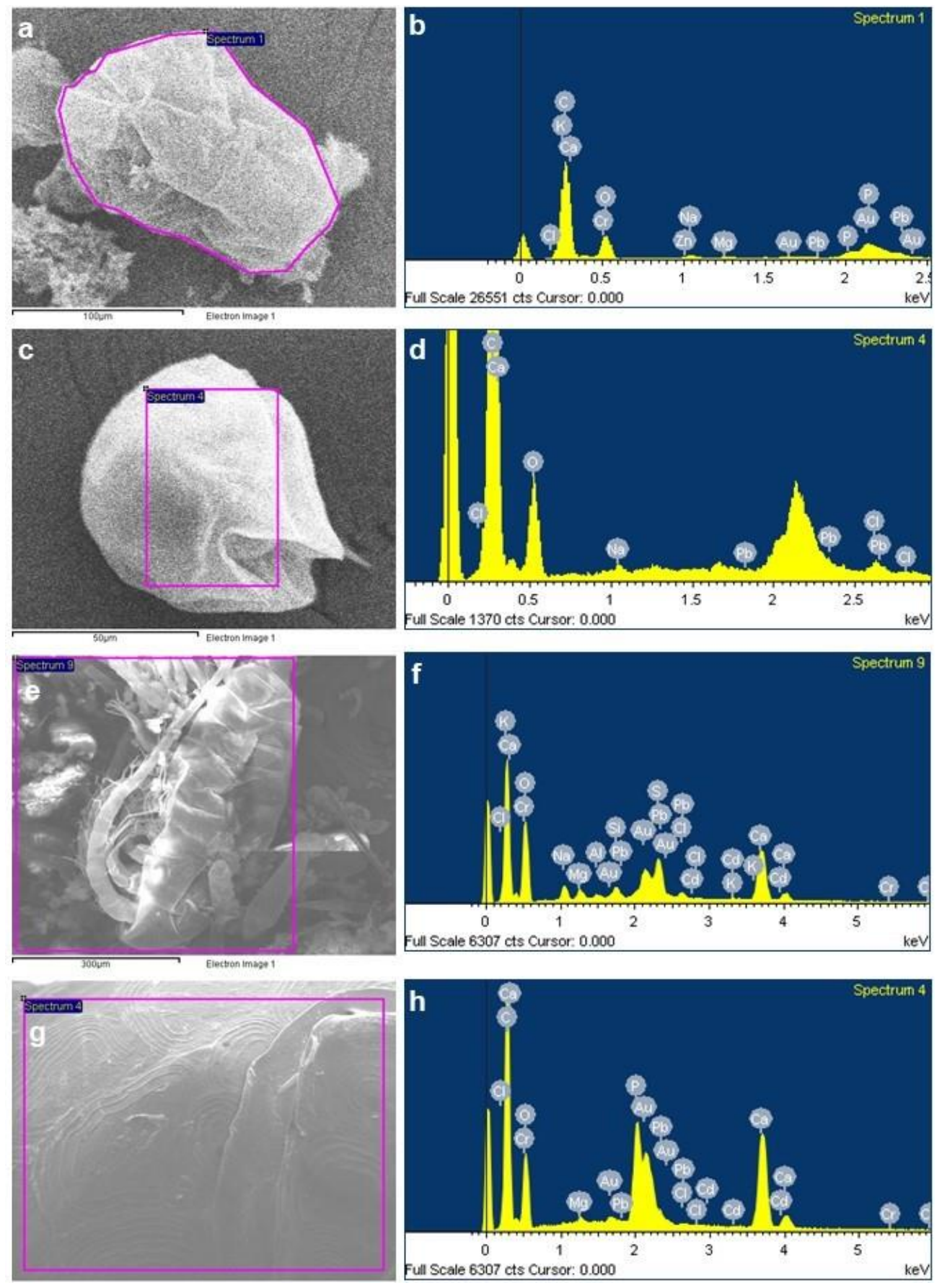

Figure 1. A representative example of X-ray spectra microanalysis of aquatic biota. a) SEM image of Brachionus cf ibericus Cancun strain, b) its spectrum of elemental composition, c) SEM image of Lecane bulla, d) its spectrum of elemental composition, e) SEM image of specimens of copepods, f) its spectrum of elemental composition, g) SEM image of scales of Fish of Gambusia yucatana, h) its spectrum of elemental composition.

Considering metal pollution, $\mathrm{Pb}$ was one of the most common elements identified in some taxonomic groups, which suggests that it is biomagnifying. In contrast, $\mathrm{Cd}$ and $\mathrm{Hg}$ were detected only in cladocerans and copepods. The presence of these metals in aquatic biota is consistent with reports of metal in Quintana
Roo. The presence of $\mathrm{Cd}$ and $\mathrm{Pb}$ has been reported in the Mexican Caribbean Sea (Fernández et al., 2007). Furthermore, $\mathrm{Pb}$ has been detected in leaves and rhizomes of the marine seagrass Thalassia testudinum in the coral reef zone of Puerto Morelos, Quintana Roo (Whelan III et al., 2011). However, it is important to 
Table 1. X-ray diffraction elemental analysis of the composition of groups of aquatic biota of northeastern Quintana Roo, Mexico. Values are mean \pm standard deviation.

\begin{tabular}{|c|c|c|c|}
\hline Element & $\begin{array}{l}\text { Cladocerans } \\
\text { (\% weight) }\end{array}$ & $\begin{array}{l}\text { Copepods } \\
\text { (\% weight) }\end{array}$ & $\begin{array}{l}\text { Rotifers } \\
\text { (\% weight) }\end{array}$ \\
\hline $\mathrm{C}$ & $55.74 \pm 2.26$ & $58.26 \pm 1.18$ & $60.41 \pm 10.31$ \\
\hline $\mathrm{O}$ & $41.05 \pm 2.20$ & $38.86 \pm 0.99$ & $31.76 \pm 6.84$ \\
\hline $\mathrm{Al}$ & $0.24 \pm 0.21$ & $0.52 \pm 0.9$ & $0.11 \pm 0.03$ \\
\hline $\mathrm{F}$ & 0 & 3.28 & 0 \\
\hline $\mathrm{Na}$ & 0 & 0 & $0.20 \pm 0.08$ \\
\hline $\mathrm{Mg}$ & $0.20 \pm 0.05$ & $0.28 \pm 0.06$ & $0.17 \pm 0.11$ \\
\hline $\mathrm{Si}$ & $0.65 \pm 0.67$ & $0.15 \pm 0.04$ & $0.41 \pm 0.33$ \\
\hline $\mathrm{P}$ & 0 & $0.31 \pm 0.13$ & $0.85 \pm 0.43$ \\
\hline S & 0.44 & $0.30 \pm 0.12$ & $1.26 \pm 1.06$ \\
\hline $\mathrm{Cl}$ & $0.11 \pm 0.04$ & $0.11 \pm 0.01$ & $0.23 \pm 0.26$ \\
\hline $\mathrm{K}$ & 0 & 0 & $0.22 \pm 0.28$ \\
\hline $\mathrm{Ca}$ & $1.64 \pm 1.08$ & $1.42 \pm 0.42$ & $1.40 \pm 0.96$ \\
\hline $\mathrm{Cu}$ & $0.32 \pm 0.02$ & $0.35 \pm 0.11$ & $0.43 \pm 0.14$ \\
\hline $\mathrm{Br}$ & $0.23 \pm 0.02$ & $1.46 \pm 1.42$ & 0 \\
\hline $\mathrm{Zn}$ & 0 & 0 & 0.96 \\
\hline $\mathrm{Fe}$ & 0 & 0 & $0.21 \pm 0.07$ \\
\hline $\mathrm{Cd}$ & 0.14 & 0.14 & 0 \\
\hline $\mathrm{Pb}$ & 0 & 0 & $0.36 \pm 0.09$ \\
\hline $\mathrm{Hg}$ & $0.64 \pm 0.33$ & 0 & 0 \\
\hline $\mathrm{Au}$ & 5.47 & 0 & $5.77 \pm 3.81$ \\
\hline $\mathrm{Rb}$ & 0.25 & 0 & 0.21 \\
\hline $\mathrm{Pt}$ & 0.69 & 0.72 & 0.73 \\
\hline
\end{tabular}

quantify the metal concentration in tissue to determine the magnitude of bioaccumulation and biomagnification and the risk posed by $\mathrm{Cd}, \mathrm{Hg}$ and $\mathrm{Pb}$ for the ecosystems of Quintana Roo (Mackay et al., 2018).

The evidence provided by our results indicates that all of these elements detected in the biota are related to the hydrogeochemistry of water. In this sense, in northeastern Quintana Roo, saline intrusion (close to the coastline), rock decoupling and anthropogenic pollution have been identified (Perry et al., 1989; Schmitter-Soto et al., 2002; Beddows et al., 2007; Gondwe et al., 2010; Hernández-Terrones et al., 2011; Metcalfe et al., 2011). For example, rock dissolution takes place in karstic systems as a result of the mixing fresh, and salt water is dissolving carbonates, as well as other processes (e.g., redox, organic oxidation and sulfate reduction), to produce a series of caverns and interconnected passages (Smart et al., 2006). In the state of Quintana Roo (Corridor Sian Ka'an-Bacalar), four types of water have been detected: calciumbicarbonate $\left(\mathrm{Ca}-\mathrm{HCO}_{3}\right)$ in places with limestone rocks,
Table 2. X-ray diffraction elemental analysis of the composition of the aquatic biota of northeastern Quintana Roo, Mexico. Values are mean \pm standard deviation.

\begin{tabular}{cccc}
\hline Element & $\begin{array}{c}\text { Dinoflagellates } \\
(\% \text { weight })\end{array}$ & $\begin{array}{c}\text { Fish } \\
(\% \text { weight })\end{array}$ & $\begin{array}{c}\text { Diatoms } \\
(\% \text { weight })\end{array}$ \\
\hline $\mathrm{C}$ & $40.80 \pm 3.47$ & $47.21 \pm 9.65$ & $19.31 \pm 2.62$ \\
$\mathrm{O}$ & $39.24 \pm 1.57$ & $30.87 \pm 5.24$ & $54.63 \pm 1.65$ \\
$\mathrm{Al}$ & $0.10 \pm 0.02$ & 0 & 0.12 \\
$\mathrm{~N}$ & 0 & 26.09 & 0 \\
$\mathrm{Na}$ & $2.86 \pm 1.08$ & $0.12 \pm 0.04$ & 0 \\
$\mathrm{Mg}$ & $0.42 \pm 0.08$ & $0.30 \pm 0.10$ & 0.13 \\
$\mathrm{Si}$ & $1.45 \pm 0.67$ & 0 & $7.13 \pm 5.41$ \\
$\mathrm{P}$ & 0 & $6.04 \pm 3.42$ & 0 \\
$\mathrm{~S}$ & $3.79 \pm 1.86$ & $0.45 \pm 0.05$ & 0 \\
$\mathrm{Cl}$ & $0.54 \pm 0.22$ & $0.20 \pm 0.09$ & 0 \\
$\mathrm{~K}$ & $0.21 \pm 0.07$ & 0 & 0 \\
$\mathrm{Ca}$ & $5.95 \pm 1.05$ & $9.92 \pm 6.22$ & $16.67 \pm 6.48$ \\
$\mathrm{Cu}$ & 0 & 0 & $0.32 \pm 0.07$ \\
$\mathrm{~Pb}$ & $0.52 \pm 0.08$ & $0.81 \pm 0.19$ & 0 \\
$\mathrm{Ag}$ & 0 & 7.51 & \\
$\mathrm{Au}$ & $4.41 \pm 0.38$ & $7.33 \pm 4.68$ & 5.49 \\
\hline
\end{tabular}

calcium magnesium chloride (mixed $\mathrm{Ca}-\mathrm{Mg}-\mathrm{Cl}$ ) in gypsum intermingled with limestone rocks, calcium sulfate $\left(\mathrm{Ca}-\mathrm{SO}_{4}\right)$ in zones of evaporitic materials, and sodium chloride $(\mathrm{Na}-\mathrm{Cl})$ close to the coastal zone (Sánchez-Sánchez et al., 2015). Overall, the elemental composition detected in the aquatic biota is related to the chemical composition and mineral elements in water, including hazardous metals. For example, cadmium salts (cadmium chloride, cadmium sulfate and cadmium nitrate) are water soluble, but other insoluble components can become more soluble by interaction with acids, light or oxygen (ATSDR, 2016). Although the YP has mainly calcium carbonate water, the co-existing reductive conditions in sulfate-rich waters in some coastal areas (Sánchez-Sánchez et al., 2015) can provide acidic conditions that could mobilize cadmium that would otherwise not be available. In this way, the biota and its elemental composition are related to the hydrogeochemistry of water. For example, in diatoms and marine dinoflagellates, the presence of $\mathrm{Ca}$, $\mathrm{K}, \mathrm{Mg}, \mathrm{P}, \mathrm{S}$ and $\mathrm{Si}$ has been reported as part of the composition of their body structure (Segura-Noguera et al., 2012). Also, variations in the concentrations of $\mathrm{Ca}$, $\mathrm{Cl}, \mathrm{K}, \mathrm{Na}, \mathrm{Mg}, \mathrm{P}, \mathrm{S}$ and $\mathrm{Si}$ in Ceratium hirundinella are caused by seasonality (Sigee et al., 1998). Moreover, Barkács et al. (1999) report that $\mathrm{Ca}, \mathrm{Cu}, \mathrm{Fe}, \mathrm{K}, \mathrm{Mn}$ and $\mathrm{Zn}$ are present in freshwater microalgae species. 


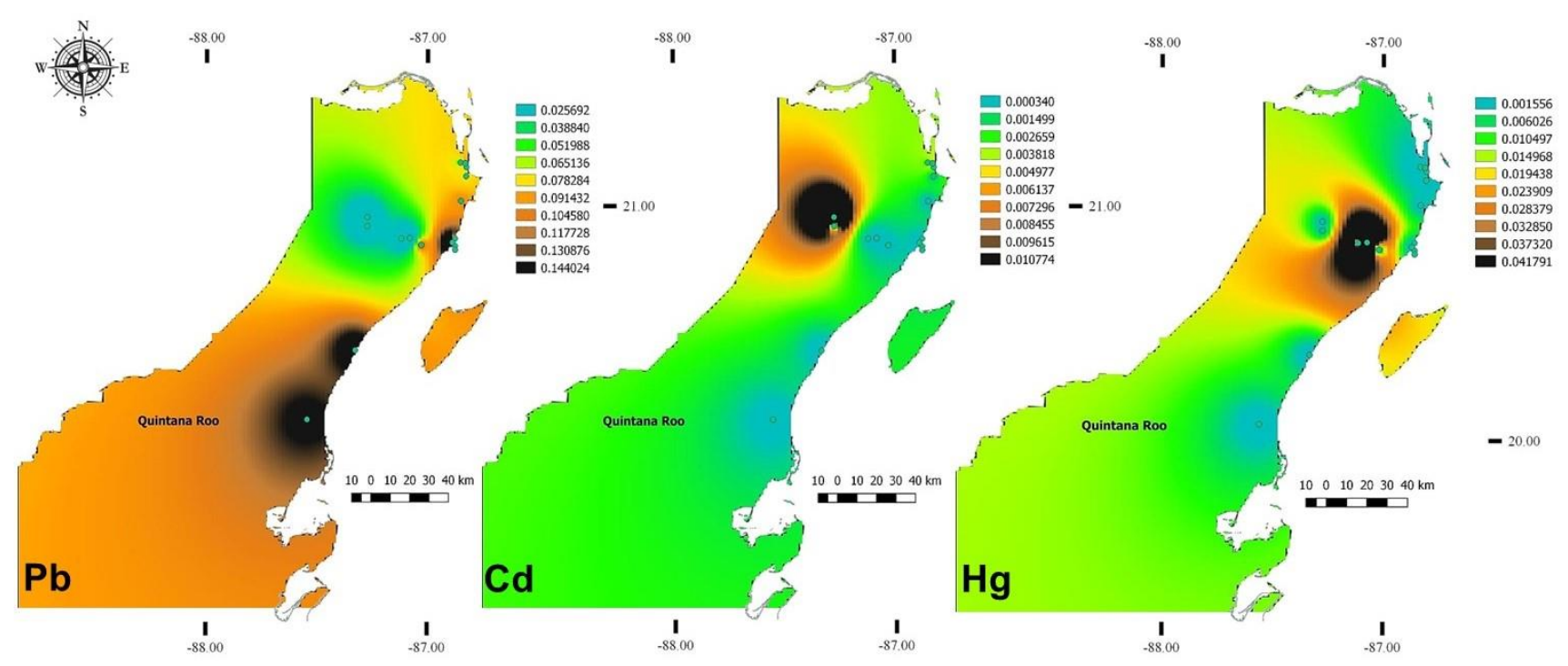

Figure 2. $\mathrm{Cd}, \mathrm{Hg}$ and $\mathrm{Pb}$ interpolation mapping using QGis software. Weighting is inverse to the distance (IDW) using the Neighbor-Joining Algorithm. Dark colors indicate high values; light colors indicate low values (see details in the colors bands).

Table 3. X-ray diffraction elemental analysis of the composition of Brachionus cf. ibericus (strains Cancun) in control organisms and organisms intoxicated with $\mathrm{Cd}, \mathrm{Cr}$ and $\mathrm{Pb}$. Values are mean \pm standard deviation and coefficient of variation (CV\%).

\begin{tabular}{ccccc}
\hline Element & $\begin{array}{c}\text { Not intoxicated } \\
\text { (\% weight) }\end{array}$ & CV\% & $\begin{array}{c}\text { Intoxicated } \\
\text { (\% weight) }\end{array}$ & CV\% \\
\hline $\mathrm{C}$ & $60.76 \pm 2.27$ & 3.73 & $59.21 \pm 6.59$ & 11.14 \\
$\mathrm{~N}$ & 0 & 0 & 27.41 & 0 \\
$\mathrm{O}$ & $40.26 \pm 11.91$ & 29.59 & $32.27 \pm 7.78$ & 24.12 \\
$\mathrm{Na}$ & $1.06 \pm 1.24$ & 117.21 & $0.65 \pm 0.74$ & 114.1 \\
$\mathrm{Mg}$ & $0.49 \pm 0.86$ & 175.47 & $0.21 \pm 0.27$ & 128.63 \\
$\mathrm{P}$ & 0 & 0 & $0.54 \pm 0.06$ & 11.9 \\
$\mathrm{~S}$ & 0 & 0 & $1.75 \pm 1.57$ & 89.7 \\
$\mathrm{Al}$ & $0.15 \pm 0.05$ & 35.28 & 0 & 0 \\
$\mathrm{Cl}$ & $1.17 \pm 1.32$ & 113.34 & $0.83 \pm 1.05$ & 127.41 \\
$\mathrm{~K}$ & 0 & 0 & 0.08 & 0 \\
$\mathrm{Ca}$ & $0.65 \pm 0.80$ & 124.4 & $0.62 \pm 0.55$ & 88.91 \\
$\mathrm{Cu}$ & 0 & 0 & $0.26 \pm 0.03$ & 12.96 \\
$\mathrm{Zn}$ & $0.32 \pm 0.1$ & 31.59 & $0.52 \pm 0.34$ & 66.38 \\
$\mathrm{Au}$ & 0 & 0 & $6.18 \pm 5.22$ & 84.45 \\
$\mathrm{~Pb}$ & 0 & 0 & $1.74 \pm 2.54$ & 145.83 \\
$\mathrm{Pt}$ & $3.47 \pm 3.76$ & 108.41 & $0.60 \pm 0.04$ & 6.77 \\
\hline
\end{tabular}

Analysis of the pattern of distribution of metals in our results suggests that the presence of $\mathrm{Cd}, \mathrm{Hg}$ and $\mathrm{Pb}$ in the biota is an indicator of pollution in the aquatic ecosystems of northeastern Quintana Roo. The aquatic biota organisms have $\mathrm{Pb}$ in their lorica and scales, with the highest levels of $\mathrm{Pb}$ bioaccumulation in aquatic biota in the coastal zone. On the other hand, the highest $\mathrm{Cd}$ accumulation was in organisms are in the species inland from the continent in the northwest direction. Besides, the highest $\mathrm{Hg}$ bioaccumulation was on the mainland heading northeast, near the coastal area (Fig. 2). In summary, the coastal and continental zones of the northeast and northwest Quintana Roo are contaminated by $\mathrm{Cd}, \mathrm{Hg}$ and $\mathrm{Pb}$. Indeed, these zones have substantial anthropogenic activity, as seen by the results of metal pollution studies by Fernandez et al. 
Table 4. X-ray diffraction elemental analysis of the composition of Lecane bulla (strains Cancun) in control organisms and organisms intoxicated with $\mathrm{Cd}, \mathrm{Cr}$ and $\mathrm{Pb}$. Values are mean \pm standard deviation and coefficient of variation $(\mathrm{CV} \%)$.

\begin{tabular}{ccccc}
\hline Element & $\begin{array}{c}\text { Not intoxicated } \\
\text { (\% weight) }\end{array}$ & CV\% & $\begin{array}{c}\text { Intoxicated } \\
\text { (\% weight })\end{array}$ & CV\% \\
\hline $\mathrm{C}$ & $64.09 \pm 0.78$ & 1.22 & $65.54 \pm 1.23$ & 1.87 \\
$\mathrm{O}$ & $34.21 \pm 1.10$ & 3.21 & $32.75 \pm 1.78$ & 5.43 \\
$\mathrm{~F}$ & 0 & 0 & 5.42 & 0 \\
$\mathrm{Na}$ & $0.55 \pm 0.12$ & 22.06 & $0.34 \pm 0.14$ & 41.55 \\
$\mathrm{P}$ & 0 & 0 & $0.02 \pm 0.06$ & 0 \\
$\mathrm{Mg}$ & $0.34 \pm 0.12$ & 34.48 & $0.24 \pm 0.08$ & 31.76 \\
$\mathrm{Cl}$ & $0.55 \pm 0.19$ & 43.07 & $0.36 \pm 0.13$ & 35.85 \\
$\mathrm{Ca}$ & $0.26 \pm 0.11$ & 0 & $0.50 \pm 0.44$ & 87.46 \\
$\mathrm{~Pb}$ & 0 & 0 & 0.93 & 0 \\
$\mathrm{Pt}$ & 0 & 0 & 0.05 & 0 \\
\hline
\end{tabular}

(2017), Medina-Elizalde et al. (2002) and Whelan III et al. (2011). However, we do not know the adverse effects of $\mathrm{Cd}, \mathrm{Hg}$ and $\mathrm{Pb}$ on human health and the aquatic biota of northeastern Quintana Roo. Hence, it is important that special attention is paid to the implementation of biomonitoring for the presence of metals considered toxic for human health and the ecosystem using ecological indicators. Ecotoxicology studies on species native to Quintana Roo are also crucial because $\mathrm{Cd}, \mathrm{Hg}$ and $\mathrm{Pb}$ are extremely toxic and dangerous metals (DeForest, 2007). Cadmium is of particularly interest for additional studies because it is notorious for its high persistence and wide distribution in underground water in the YP; concentrations ranging from 0.02 to $0.062 \mathrm{mg} \mathrm{L}^{-1}$ have been reported. These values exceed the maximum permissible limit of 0.005 $\mathrm{mg} \mathrm{L}^{-1}$ set by the current Mexican normativity (NOM127-SSA1-1994) and the limits of $0.01 \mathrm{mg} \mathrm{L}^{-1}$ in water and $0.1 \mathrm{mg} \mathrm{L}^{-1}$ for protection of aquatic life set by the Ley Federal de Derechos en Materia de Agua (Federal Law on Water Rights) (Avila et al., 2012). In Quintana $\mathrm{Roo}, \mathrm{Hg}$ has been detected in water in the range 0.1 to $0.7 \mathrm{mg} \mathrm{L}^{-1}$ (Rojas-Mingüer \& Morales-Vela, 2002), whereas $\mathrm{Pb}$ ranges from 0.0001 to $50 \mathrm{mg} \mathrm{L}^{-1}$ (Fernández et al., 2007).

The laboratory experiments with two rotifer species demonstrated that $\mathrm{Cd}$ does not bioaccumulate under experimental conditions, and these results agree with our analyses of rotifer field species. In contrast, $\mathrm{Pb}$ does bioaccumulate, which is also consistent with the results of the field studies. Accordingly, $\mathrm{Pb}^{+2}$ bioaccumulates in rotifers, but apparently, $\mathrm{Cd}^{+2}$ do not. This finding suggests that the mechanisms of toxicity and detoxification are different between $\mathrm{Cd}^{+2}$ and $\mathrm{Pb}^{+2}$. This conclusion was drawn from scarce data on bioaccumulation factors (BAF) and bioconcentration factor
(BCF). To expand this information, we revised the bioconcentration factor (BCF) data and analyzed the elemental composition of rotifers published in the scientific literature (Table 4). The BCF is the concentration of the chemical in the organism divided by the concentration in the water column or sediment (depending on the habitat of the model organism) and is usually calculated in the laboratory (Gobas \& Morrison, 2000; Walker et al., 2006). On the other hand, the BAF is the concentration of a chemical that a model organism bioaccumulates through all possible exposure routes, including dietetic absorption and transportation through the respiratory surface (DeForest, 2007). Particularly for rotifers studies, BAF is higher than $\mathrm{BCF}$, evidence of biomagnification; in fact, both factors are valuable as an exposure indicator because metals are not metabolized.

In conclusion, elemental microanalysis of the aquatic biota using X-ray is a powerful tool for aquatic and toxicological biomonitoring of hazardous metals. The presence of metals in aquatic biota indicates the following: 1) during their life cycle the biota was exposed to the metal, 2) the metal was bioavailable in the water, and 3) biomagnification has occurred as evidenced by the presence of metals in different groups of aquatic organisms. Finally, it is important to consider that the contamination of metals in aquatic ecosystems is complex. Heavy metals are toxic when the total bioavailability reaches its maximum limit of assimilation and excretion. Some heavy metals can be incorporated into the body and, depending on the availability; these metals can cause a toxic effect or be stored to carry out interactions in the body without a toxic effect (Walker et al., 2006). Once the metal has accumulated, it can be divided into two forms; namely, detoxified metal and metal available to play a role in metabolism (Rainbow \& Luoma, 2011). For instance, the metal enters the body of aquatic biota from any of the routes of uptake that are initially available metabolically, but will soon need to be excreted or inactivated to avoid being toxic. Toxicity occurs when the rate of uptake of metal exceeds the combined rates of excretion and detoxification of that metal. Under these conditions, the metal will remain longer in the body causing an accumulation that at the time of exceeding the limits could provoke effects toxic and harmful to the organism (Rainbow \& Luoma, 2011). Because of these findings, it is important that the water quality in Mexico be measured from physical, chemical and biological approaches. Our method is a powerful alternative tool to understand the movements of metals in ecosystems, which is information that can be used as a first estimation of metal pollution and to define strategies for future investigations and monitored hazardous metal pollution. 


\section{ACKNOWLEDGMENTS}

The authors thank Maria Goretti Campos-Ríos, Ailem Guadalupe Marin Chan, Cecilia Hernández Zepeda, Gabriela Rosiles González, and Francisco Valadez. We also thank the staff of CONANP and Sian Ka'an Biosphere, Quintana ROO, México. The present work was supported by CONABIO JF012, CICY-CIO 2016, and CONACYT N ${ }^{\circ} 2944$.

\section{REFERENCES}

Alvarado-Flores, J. \& Rico-Martínez, R. 2017. Bioconcentration of lead and $\mathrm{x}$-ray microanalysis with SEM in the freshwater rotifer Lecane quadridentata (Rotifera: Monogonta). Polish Journal of Environmental Studies, 26: 1-4.

Alvarado-Flores, J., Rico-Martínez, R., Ventura-Juárez, J., Silva-Briano, M. \& Rubio-Franchini, I. 2012. Bioconcentration and localization of lead in the freshwater rotifer Brachionus calyciflorus Pallas 1677 (Rotifera: Monogononta). Aquatic Toxicology, 109: 127-132.

Álvarez-Cadena, J.N., Ordóñez-López, U., AlmaralMendivil, A.R. \& Uicab-Sabido, A. 2007. Composition and abundance of zooplankton groups from a coral reef lagoon in Puerto Morelos, Quintana Roo, Mexico, during an annual cycle. Revista de Biología Tropical, 57(3): 647-658.

Avila, P.J., Sansores A.C., Quintal, M.B., Can, L.A. \& Perera, M.C. 2012. Environmental study on cadmiumin groundwater in Yucatán. In: Oswald-Spring, U. (Ed.). Water resources in Mexico. Springer, Berlin, pp. 239249.

Barkács, K., Varga, A., Gál-Solymos, K. \& Záray, G. 1999. Direct determination of metal concentrations in freshwater algae by total reflection X-ray fluorescence spectrometry. Journal of Analytical Atomic Spectrometry, 14: 577-581.

Beddows, P.A., Smart, P.L., Whitaker, F.F. \& Smith, S.L. 2007. Decoupled fresh-saline groundwater circulation of a coastal carbonate aquifer: spatial patterns of temperature and specific electrical conductivity. Journal of Hydrology, 346: 18-32.

Bernard, A. 2008. Cadmium \& its adverse effects on human health. Indian Journal Medical Research, 128(4): 557-564.

Comisión Nacional del Agua (CNA). 2016. Atlas del agua en México. Comisión Nacional del Agua, Coyoacán.

DeForest, D.K., Brix, K.V. \& Adams, W.J. 2007. Assessing metal bioaccumulation in aquatic environments: the inverse relationship between bioaccumulation factors, trophic transfer factors, and exposure concentration. Aquatic Toxicology, 84: 236-246.

Elías-Gutiérrez, M., Suárez-Morales, E., GutiérrezAguirre, M.A., Silva-Briano, M., Granados-Ramírez, J.G. \& Garfias-Espejo, T. 2008. Cladocera y Copepoda de las aguas continentales de México. Guía Ilustrada. Comisión Nacional para el Conocimiento y Uso de la Biodiversidad: Consejo Nacional de Ciencia y Tecnología: Secretaría de Medio Ambiente y Recursos Naturales, México D.F.

Fernández, A., Singh, A. \& Jaffé, R. 2007. A literature review on trace metals and organic compounds of anthropogenic origin in the Wider Caribbean Region. Marine Pollution Bulletin, 54: 1681-1691.

Gobas, F.M. \& Morrison, H. 2000. Bioconcentration and biomagnification in the aquatic environment. In: Mackay, D. \& Boethling, R. (Eds.). Handbook of property estimation methods for chemicals. CRC Press, Florida.

Gómez, A.G.G., Ramos, R.R. \& Salazar, H.T.C. 2016. Aprovechamiento de las escamas de la industria acuícola en el departamento del Huila, Colombia. Producción + Limpia, 11(2): 102-110.

Gondwe, B.R.N., Lerer, S., Stisen, S., Marín, L., Rebolledo-Vieyra, M., Merediz-Alonso, G. \& BauerGottwein, P. 2010. Hydrogeology of the southeastern Yucatan Peninsula: new insights from water level measurements, geochemistry, geophysics, and remote sensing. Journal of Hydrology, 389: 1-17.

Hernández-Arana, H.A., Vega-Zepeda, A., Ruíz-Zárate, M.A., Falcón-Álvarez, L.I., López-Adame, H., Herrera-Silveira, J. \& Kaster, J. 2015. Transverse coastal corridor: from freshwater lakes to coral reefs ecosystems. In: Islebe, G., Calmé, S., León-Cortés, J. \& Schmook, B. (Eds.). Biodiversity and conservation of the Yucatán Peninsula. Springer, Berlin, pp. 355376.

Hernández-Terrones, L., Rebolledo-Vieyra, M., MerinoIbarra, M., Soto, M., Le-Cossec, A. \& Monroy-Ríos, E. 2011. Groundwater pollution in a karstic region (NE Yucatan): baseline nutrient content and flux to coastal ecosystem. Water, Air \& Soil Pollution, 218: 517-528.

Herrera-Silveira, J. \& Comín, F. 2000. An introductory account of the types of aquatic ecosystems of Yucatan Peninsula (SE Mexico). In: Munavar, M., Lawrence, S., Munavar, I. \& Malley, D. (Eds.). Aquatic ecosystems of Mexico: status \& scope. Backhuys Publishers, Leiden, pp. 213-227.

Juárez-de la Rosa, B.A., May-Crespo, J., Quintana-Owen, P., González-Gómez, W.S., Yáñez-Limón, J.M. \& Alvarado-Gil, J.J. 2015. Thermal analysis and structural characterization of chitinous exoskeleton from two marine invertebrates. Thermochimica Acta, 610: 16-22. 
Koste, W. 1978. Rotatoria Die Rädertiere Mitteleuropas. Gebrüder Borntraeger, Stuttgart.

Landis, W.G. \& Yu, M.-H. 2004. Introduction to environmental toxicology: impacts of chemical upon ecological systems. Lewis Publisher, Florida.

Mackay, D., Celsie, A.K.D., Powell, D.E. \&. Parines, J.M. 2018. Bioconcentration, bioaccumulation, biomagnification and trophic magnification: a modelling perspective. Environmental Science: Processes \& Impacts, 20: 72-85.

Medina-Elizalde, M., Gold-Bouchot, G. \& Ceja-Moreno, V. 2002. Lead contamination in the Mexican Caribbean recorded by the coral Montastraea annularis (Ellis \& Solander). Marine Pollution Bulletin, 44: 421-431.

Metcalfe, C.D., Beddows, P.A., Bouchot, G.G., Mecalfe, T.L., Li, H. \& Van Lavieren, H. 2011. Contaminants in the coastal karst aquifer system along the Caribbean coast of the Yucatan Peninsula, Mexico. Environmental Pollution, 159(4): 991-997.

Mudgal, V., Madaan, N., Mudgal, A., Singh, R.B. \& Mishra, S. 2010. Effect of toxic metals on human health. The Open Nutraceutical Journal, 3: 94-99.

Newbury, D.E. \& Ritchie, N.W.M. 2013. Is scanning electron microscopy/energy dispersive X-ray spectrometry (SEM/EDS) quantitative? Scanning, 35: 141168.

Nichols, H.W. 1973. Growth media-freshwater. In: Stein, R. (Ed.). Handbook of physiological methods. University Press, Cambridge, pp. 7-24.

Nogrady, T. \& Pourriot, R. 1995. Rotifera: the Notommatidae. In: Nogrady, T., Koste, W., Shiel, R.J. \& Dumont, H.J.F. (Eds.). Guides to the identification of microinvertebrates of the continental waters of the world. SPB Academic Publishing, Leiden.

Nogrady, T. \& Segers, H. 2002. Rotifera: Asplanchnidae, Gastropodidae, Lindiidae, Microcodidae, Synchaetidae, Trochosphaeridae and Filinia. In: Dumont, H.J.F. (Ed.). Guides to the identification of microinvertebrates of the continental waters of the world. SPB Academic Publishing, Leiden.

Oliva, S.R. \& Fernández-Espinosa, A.J. 2007. Monitoring of heavy metals in topsoils, atmospheric particles, and plant leaves to identify possible contamination sources. Microchemical Journal, 86: 131-139.

Péqueux, A. \& Lignon, J. 1991. Perméabilité cuticulaire et ionorégulation chez les crustacés décapodes. Cahiers de Biologie Marine, 32: 203-211.

Pérez-Legaspi, I.A. \& Rico-Martínez, R. 1998. Effect if temperature and food concentration in two species of littoral rotifers. Hydrobiology, 387-388: 341-348.
Perry, E.C., Swift, J., Gamboa, J., Reeve, A., Sanborn, R., Marin, L. \& Villasuso, M. 1989. Geological and environmental aspect of surface cementation, north coast, Yucatan, Mexico. Geology, 17: 17-20.

Rainbow, P.S. \& Luoma, S.N. 2011. Metal toxicity, uptake and bioaccumulation in aquatic invertebratesModelling zinc in crustaceans. Aquatic Toxicology, 101(1): 455-465.

Rico-Martínez, R. \& Silva-Briano, M. 1993. Contribution to the knowledge of the Rotifera of Mexico. Hydrobiologia, 255-256: 467-474.

Rojas-Mingüer, A. \& Morales-Vela, B. 2002. Metales en hueso y sangre de manatíes de 293 (Trichechus manatus manatus) de la Bahía de Chetumal, Quintana Roo, México. In: Rosado-May, F.J., Romero-Mayo, R. \& De Jesús-Navarrete, A. (Eds.). Contribuciones de la ciencia al manejo costero integrado de la Bahía de Chetumal y su área de influencia. Universidad de Quintana Roo, Chetumal, pp. 133-142.

Rubio-Franchini, I., Mejía-Saavedra, J.J. \& RicoMartínez, R. 2008. Determination of lead in samples of zooplankton, water, and sediments in a Mexican reservoir: evidence for lead biomagnification in lower/intermediate trophic levels? Environmental Toxicology, 23: 459-465.

Rubio-Franchini, I., López-Hernández, M., RamosEspinosa, M.G. \& Rico-Martínez, R. 2016. Bioaccumulation of metals arsenic, cadmium, and lead in zooplankton and fishes from the Tula River watershed Mexico. Water, Air \& Soil Pollution, 227: 5.

Sánchez-Sánchez, J.A., Álvarez-Legorreta, T.A., PachecoÁvila, J.G., González-Herrera, R.A. \& CarrilloBribiezca, L.C. 2015. Caracterización hidrogeoquímica de las aguas subterráneas del sur del estado de Quintana Roo, México. Revista Mexicana de Ciencias Geológicas, 32: 62-76.

Schmitter-Soto, J.J., Comín, F.A., Escobar-Briones, E., Herrera-Silveira, J., Alcocer, J., Suárez-Morales, E., Elías-Gutiérrez, M., Díaz-Arce, V., Marín, L.E. \& Steinich, B. 2002. Hydrogeochemical and biological characteristic of cenotes in the Yucatan Peninsula (SE Mexico). Hydrobiologia, 467: 215-228.

Segura-Noguera, M., Blasco, D. \& Fortuño, J.M. 2012. An improved energy-dispersive X-ray microanalysis method for analyzing simultaneously carbon, nitrogen, oxygen, phosphorus, sulfur, and other cation and anion concentrations in single natural marine microplankton cells. Limnology and Oceanography: Methods, 10: 666-680.

Sigee, D.C., Krivtsov, V. \& Bellinger, E.G. 1998. Elemental concentrations, correlations, and ratios in micro-populations of Ceratium hirundinella (Pyrrhophyta): an X-ray microanalytical study. European Journal of Phycology, 33: 155-164. 
Smart, P.L., Beddows, P.A., Coke, J., Doerr, S., Smith, S. \& Whitaker, F.F. 2006. Cave development on the Caribbean coast of the Yucatan Peninsula, Quintana Roo, Mexico. Special Paper of the Geological Society of America, 404, 105-128.

Stemberger, R.S. 1979. A guide to rotifers of the Laurent Great Lakes. Environmental monitoring and support laboratory office of Research and Development U.S Environmental Protection Agency, Cincinnati.

Sternbeck, J., Sjödin, A. \& Andreasson, K. 2002. Metal emissions from road traffic and the influence of resuspension. Atmospheric Environment, 36: 47354744.

Suárez-Morales, E., Ordóñez-López, U. \& VásquezYeomans, L. 2013. Las investigaciones de zooplancton marino en el sureste de México (1985-2010): logros y perspectivas institucionales. Sociedad y Ambiente, 1(1): 96-112.

Received: 14 January 2019; Accepted: 9 May 2019
Tchounwou, P.B., Yedjou, C.G., Patlolla, A.K. \& Sutton, D.J. 2012. Heavy metal toxicity and the environment. In: Luch, A. (Ed.). Molecular, clinical and environmental toxicology. Experientia Supplementum. Vol 101. Springer, Basel.

Torrescano-Valle, N. \& Islebe, G.A. 2015. Holocene paleoecology, climate history and human influence in the southwestern Yucatan Peninsula. Review of Palaeobotany and Palynology, 217: 1-8.

US Environmental Protection Agency. 1985. Methods for measuring the acute toxicity of effluents to freshwater and marine organisms. US Environmental Protection Agency, Washington.

Walker, C.H., Hopkin, S.P., Sibly, R.M. \& Peakall, D.B. 2006. Principles of ecotoxicology. Taylor \& Francis, New York.

Whelan III, T., Van Tussenbroek, B.I. \& Barba Santos, M.G. 2011. Changes in trace metals in Thalassia testudium after hurricane impacts. Marine Pollution Bulletin, 62: 2797-2802. 